\title{
PKM Perilaku Sadar Sampah Bagi Siswa
}

\author{
Muhammad Eko Atmojo, Sakir, Mahendro Prasetyo Kusumo, Anwar Kholid \\ Universitas Muhammadiyah Yogyakarta \\ Email: atmojoeko91@gmail.com
}

\begin{abstract}
Abstrak
Tujuan dari kegiatan ini adalah untuk membantu penanggulangan permasalahan sampah di masyarakat melalui Program Perilaku Sadar Sampah Bagi Siswa di SD Negeri Singoyudan Kecamatan Mirit Kabupaten Kebumen. Adapun metode yang digunakan yaitu melalui Forum Group Discussion (FGD) dan Sosialisasi. FGD salah satu metode yang kami gunakan, dengan adanya metode ini kami berharap mendapatkan informasi maupun data mengenai perilaku siswa dalam membuang sampah di sekolah. Hasil dari kegiatan ini diperoleh yakni adanya beberapa kegiatan yang kami lakukan di SD Negeri Singoyudan Kecamatan Mirit Kabupaten Kebumen bisa membantu guru dan siswa dalam memahami pemilahan sampah maupun pengelolaan sampah melalui 3R. Dengan adanya pemahaman tersebut maka akan tertanam kepada siswa mengenai cinta lingkungan dan kebersihan sehingga pendidikan karakter dalam membuang sampah kepada siswa bisa berhasil.
\end{abstract}

Kata Kunci: Pendidikan Dini, Pemilahan Sampah, dan Pengelolaan Sampah

\begin{abstract}
The purpose of this activity is to help tackle the problem of waste in the community through the Waste Awareness Behavior Program for Students at Singoyudan State Elementary School, Mirit District, Kebumen Regency. The method used is through the Forum Group Discussion (FGD) and socialization. FGD is one of the methods we use, with this method we hope to get information and data about student behavior in throwing garbage at school. The results of this activity were that there were several activities that we did at Singoyudan State Elementary School, Mirit District, Kebumen Regency, which could help teachers and students understand waste sorting and waste management through $3 R$. With this understanding, it will be embedded in students about love for the environment and cleanliness so that character education in throwing garbage to students can be successful.
\end{abstract}

Key Words: Early Education, Garbage Sorting, and Garbage Management.

\section{PENDAHULUAN}

Permasalahan mengenai sampah sampai saat ini masih menjadi permasalahan utama di Indonesia maupun dunia, terlebih mengenai sampah yang tidak mudah terurai seperti plastic. Hal ini tidak terlepas dari meningkatnya jumlah penduduk setiap tahunnya sehingga volume sampah setiap tahun bisa meningkat. Dengan banyaknya jumlah penduduk di Indonesia dan 
minimnya pendidikan atau edukasi mengenai sampah maka akan menambah beban negara menjadi kategori negara penyumbang sampah di dunia. Pada saat ini menurut Jambeck dkk (2015) saat ini Indonesia berada di posisi kedua penyumbang sampah plastik terbesar ke laut setelah Tiongkok, sementara posisi ketiga sampai dengan kelima ditempati oleh Filipina, Vietnam, dan Sri Lanka.

Dengan posisi Indonesia sebagai negara kedua penyumbang sampah seharusnya ada inovasi dari pemerintah untuk mengurangi sampah. Inovasi tersebut bisa dilakukan melalui edukasi kemasyarakat maupun memasukkan pendidikan sampah mulai di tingkat TK-SMA. Dengan adanya edukasi yang dilakukan harapannya vlume sampah di Indonesia akan berkurang, mengingat pada tahun 2016 Greeneration seperti dikutip oleh National Geographic Indonesia (2016) menyatakan bahwa jumlah produksi sampah Indonesia pada tahun 2016 sudah mencapai angka rata-rata 175.000 ton/hari atau setara dengan 64 juta/tahun sedangkan angka pendaurulangan sampah di Indonesia masih tergolong rendah, yakni di bawah $50 \%$. Dengan data tersebut maka sangat penting bagi pemerintah untuk melakukan edukasi kepada masyarakat dalam mengurangi sampah.

Dengan adanya data tersebut menunjukkan bahwasannya beban bumi untuk menerima volume sampah setiap tahunnya berpotensi meningkat, hal ini dapat dilihat dari pernyataan Hoornweg dan Bhada-Tata (2012) bahwa produksi sampah padat secara global pada satu decade yang lalu mencapai 0,68 miliar ton/tahun. Angka ini meningkat menjadi 1,3 miliar ton/tahun pada dekade ini dan diprediksi akan terus meningkat hingga 2,2 miliar ton/tahun pada tahun 2025. Produksi sampah padat di wilayah Asia Pasifik pada dekade ini diperkirakan sebanyak 270 juta ton/tahun. Jika tidak ada usaha untuk mengubah keadaan ini maka diproyeksikan produksi sampah di Asia Pasifik ini akan terus meningkat dan mencapai puncaknya pada tahun 2075 (Hoornweg, Bhada-Tata, \& Kennedy, 2013).

Dengan beberapa data tersebut dapat kita ketahui bahwasannya masyarakat kita masih sangat acuh terhadap sampah, hal ini karena kurangnya pendidikan atau pengetahuan mengenai pengelolaan sampah. Dengan minimnya pendidikan dan pengelolaan sampah maka masyarakat akan mengabaikan sampah berserakan. Padahal jika kita lihat bahwa sampah merupakan sumber utama dalam beberapa bencana seperti banjir dan lain-lain. Selain itu sampah juga akan sangat berbahaya bagi kehidupan manusia, karena dengan banyaknya tumpukan sampah akan menghasilkan methane yang merupakan gas rumah kaca sehingga dapat menjadi salah satu penyebab perubahan iklim (climate change). Sedangkan bahaya tumpukan atau hamburan sampah yang lain akan menjadi ancaman bagi ekosistem kehidupan satwa liar yang pada akhirnya akan menjadi dampak buruk bagi kehidupan manusia.

Berdasarkan permasalahan tersebut kami bermaksud untuk mengajukan usulan pengabdian masyarakat yang bertujuan untuk membantu penanggulangan permasalahan sampah di masyarakat melalui Program Perilaku Sadar Sampah Bagi Siswa di SD Negeri Singoyudan Kecamatan Mirit Kabupaten Kebumen. Melalui Sekolah Dasar, nilai-nilai perilaku yang berwawasan ramah lingkungan dan alam dapat ditanamkan sejak dini kepada anak-anak.

\section{METODE}

Demi mendapatkan hasil yang maksimal maka pengabdian masyarakat di SD Negeri Singoyudan ini menggunakan beberapa metode salah satunya adalah sebagai berikut: 


\section{Khalayak Sasaran}

Sasaran pengabdian masyarakat ini adalah guru dan siswa-siswi Sekolah Dasar Negeri Singoyudan Kecamatan Mirit Kabupaten Kebumen.

\section{Metode Kegiatan \\ Forum Group Discussion (FGD)}

Forum group discussion salah satu metode yang kami gunakan, dengan adanya metode ini kami berharap mendapatkan informasi maupun data mengenai perilaku siswa dalam membuang sampah di sekolah. Sehingga dengan data yang kami dapatkan dari FGD tersebut akan kami tindak lanjuti kepada siswa-siswi dalam hal pemahaman atau pengetahuan mengenai perilaku membuang sampah/mengelola sampah.

\section{Sosialisasi}

Sosialisasi ini digunakan untuk memberi pemahaman kepada siswa-siswi Sekolah Dasar Singoyudan Kecamatan Mirit Kabupaten Kebumen. Dengan adanya sosialisasi ini harapan kami adalah siswa-siswi bisa paham mengenai perilaku membuang sampah maupun pengelolaan sampah di sekitarnya.

\section{HASIL DAN PEMBAHASAN}

Peningkatan pengetahuan dalam pengelolaan sampah merupakan salah satu faktor penting yang harus dilakukan kepada siswa sejak usia dini. Mengingat banyak sekali perilaku siswa-siswi yang belum paham mengenai pengelolaan sampah, sehingga banyak sekali perilaku siswa sekolah yang membuang sampah begitu saja. Hal ini menunjukkan bahwa tata kelola pengelolaan sampah belum ditanamkan kepada masyarakat sejak sejak usia dini. Selain itu kalau kita lihat masih banyak juga perilaku masyarakat kita yang mengelola sampah dengan cara dibakar atau dibuang begitu saja. Hal ini juga menunjukkan belum adanya kesadaran dari masyarakat dalam mengelola sampah. Maka dari itu perlu adanya sosialisasi secara masal mengenai pengelolaan sampah bagi anak-anak Taman Kanak-Kanak maupun Sekolah Dasar. Karena jika sejak usia dini sudah ditanamkan mengenai pengelolaan sampah dengan baik maka dia akan bisa menerapkan dengan baik dalam pengelolaan sampah.

Salah satu permasalahan yang ada di dunia pada saat ini adalah dengan banyaknya sampah yang menumpuk serta banyaknya sampah yang dihasilkan dari manusia. Hal ini juga salah satu permasalahan yang memerlukan perhatian khusus terutama di Indonesia, maupun di beberapa negara lain seperti China, Filliphina dan lain-lain. Karena sampai dengan saat ini sampah masih menjadi permasalahan klasik di dunia. Untuk mengurai sampah yang sudah mengotori bumi harus ada beberapa metode yang bisa digunakan misalkan dengan cara menghancurkan menggunakan mesin serta membakar dan lain-lain, akan tetapi hal ini belum efektif. Maka dari itu perlu adanya pendidikan mengenai pengelolaan sampah sejak usia dini, sehingga masyarakat mempunyai pengetahuan mengenai pengelolaan sampah. Maka dari itu kami melakukan pelaksanaan pengabdian mengenai perilaku membuang sampah bagi siswa di SD Negeri Singoyudan Kecamatan Mirit Kabupaten Kebumen, harapan kami dengan adanya pengabdian ini bisa membantu siswa terutama dalam pemahaman pengelolaan sampah.

Dalam pelaksanaanya ada 2 metode yang digunakan untuk mendeteksi atau memberi pemahaman kepada guru maupun sisiwa dalam hal perilaku membuang sampah. Adapun 
metode yang digunakan adalah forum group discussion (FGD) dan sosialisasi langsung kepada siswa-siswi SD Negeri Singoyudan Kecamatan Mirit Kabupaten Kebumen. Berikut ini adalah salah satu metode yang digunakan untuk menjaring pemahaman guru dalam mengelola sampah disekitarnya.

\section{a) Forum Group Discussion (FGD)}

Pada tahap pemahaman perilaku dalam membuang sampah kami telah melakukan beberapa metode, adapun metode pertama yang akan dilakukan adalah forum group discussion (FGD). Dimana dalam kegiatan FGD ini yang terlibat secara langsung adalah guru, hal ini dilakukan supaya ada pemahaman terlebih dahulu kepada guru mengenai perilaku membuang sampah. Mengingat ada beberapa pribahasa yang memang mencontohkan bahwa guru memang harus memberikan contoh yang baik kepada muridnya, berikut adalah pribahasa yang sering digunakan guru di gugu lan ditiru. Dengan pribahasa tersebut secara tidak langsung menunjukkan bahwa guru merupakan salah satu panutan untuk di percaya dan diikuti. Maka dari itu konsep kami mengenai pengabdian ini kami lebih mendahulukan pemahaman perilaku membuang sampah kepada guru terlebih dahulu, sehingga jika guru sudah bisa memahami tentang perilaku membuang sampah maka akan sangat mudah sekali untuk menerapkan peraturan tersebut kepada muridnya.

Dari kegiatan yang telah kami lakukan masih banyak sekali guru yang belum memahami perilaku dalam membuang sampah, hal ini terlihat dari pengetahuan guru yang belum banyak mengerti mengenai metode dalam pengelolaan sampah. Dalam dunia manajemen pengelolaan sampah terdapat 3 metode yang bisa digunakan dalam mengelola sampah diantaranya adalah reduce, reuse, dan recycle atau sering disebut dengan 3R. Dari beberapa metode tersebut mayoritas guru di SD Negeri Singoyudan masih banyak yang belum mengetahuinya, dan mereka lebih banyak mengetahui metode pengelolaan sampah hanya dengan dibakar saja.

Berdasarkan hal tersebut maka sangatlah penting untuk dilakukan sosialisasi atau peningkatan pengetahuan pengelolaan sampah bagi guru dan siswa Sekolah Dasar. Dengan adanya sosialisasi atau peningkatan pengetahuan diharapkan akan memberikan dampak positif bagi lingkungan di SD Negeri Singoyudan khususnya bagi guru dan siswa. Ketika pemahaman guru tentang pengelolaan sampah meningkat maka secara tidak langsung ada dampak positif di lingkungan sekolah, dimana guru pasti akan menyalurkan pengetahuannya kepada siswanya supaya menjaga kebersihan di lingkungan sekolah.

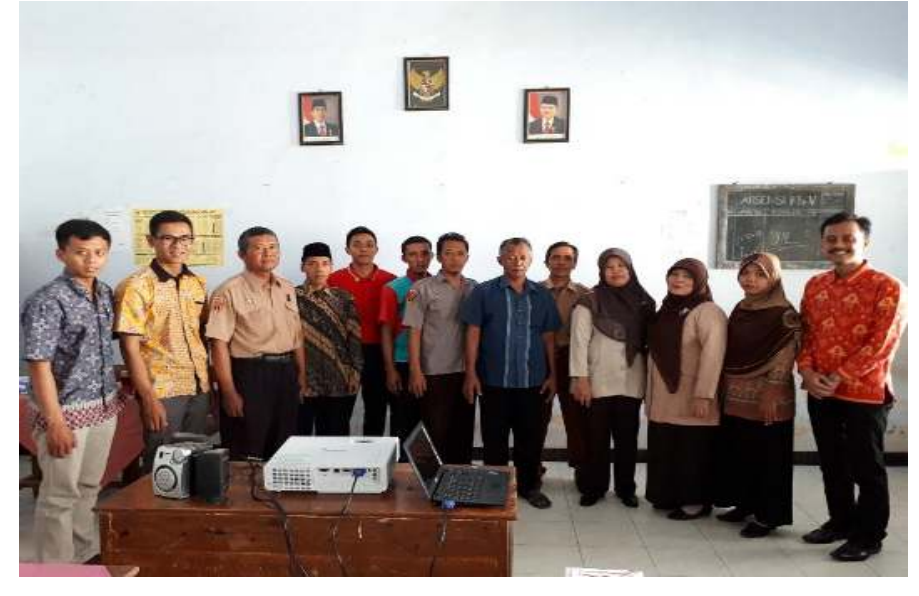




\section{Gambar 1. Kegiatan Forum Group Discussion dengan Guru}

Sumber: Dokumentasi Tim Pengabdian 2019

Pada pelaksanaan forum group discussion yang kami lakukan ada beberapa guru menyampaikan bahwa pemahaman siswa belum merata terutama pemahaman mengenai sampah baik sampah dengan jenis organic maupun sampah anorganic. Maka dari itu perlu adanya sosialisasi khusus kepada siswa yang membahas mengenai sampah organic dan sampah anorganik. Sehingga dengan adanya sosialisasi khusus kepada siswa ini diharapkan siswa bisa memahami mengenai jenis sampah.

Selain itu pada kegiatan FGD juga diutarakan bahwa perlu adanya peningkatan pengetahuan atau pemahaman kepada siswa tentang pengelolaan sampah. Jika dari usia dini sudah diberi pemahaman mengenai pengelolaan sampah maka harapannya kedepan bisa mengimplementasikan pengelolaan sampah dengan benar, setidaknya dilingkungan sekolah maupun di rumah. Dengan terbentuknya pendidikan karakter terhadap anak dalam mengelola sampah maka akan sangat bermanfaat sekali untuk menjaga lingkungan, mengingat sampah pada saat ini masih menjadi permasalahan utama bagi Indonesia maupun dunia.

\section{b) Sosialisasi Perilaku Siswa dalam Membuang Sampah}

Selain forum group discussion metode yang digunakan pada kegiatan ini adalah metode sosialisasi kepada siswa-siswi mengenai perilaku membuang sampah. Mengingat sasaran dalam pelaksanaan pengabdian ini adalah guru dan siswa maka 2 metode tadi harus dijalankan atau dilakukan kepada guru dan siswa. Tujuan diadakan dua metode tersebut adalah untuk menjaring pemahaman guru dan siswa dalam pengelolaan sampah. Sehingga ketika penyampaian materi tentang pengelolaan sampah bisa menyampaikan beberapa hal yang sesuai dengan kebutuhan.

Dalam pelaksanaan kegiatan sosialisasi yang telah kami lakukan bahwa pemahaman siswa mengenai pengelolaan sampah belum merata, sehingga perlu adanya peningkatan pengetahuan kepada siswa terutama dalam hal pengelolaan sampah. Salah satu peningkatan pengetahuan yang bisa dilakukan adalah dengan cara sosialisasi kepada siswa secara langsung mengenai pengelolaan sampah. Dalam pelaksanaan sosialisasi bisa diberikan materi mengenai klasifikasi sampah baik organic dan anorganik serta pengelolaan sampah melalui metode pemilahan sampai dengan 3R. Selain itu hal yang paling mudah dalam pelaksanaan sosialisasi kepada siswa adalah mengajarkan bagaimana cara memilah sampah terutama dalam hal membuang sampah kedalam tong sampah atau tempat sampah.

Pengajaran atau pendidikan dalam membuang sampah merupakan salah satu pendidikan karakter yang harus ditanamkan kepada anak-anak usia dini. Salah satu tujuan pendidikan karakter yang ditanamkan kepada anak-anak adalah perilaku membuang sampah pada tempatnya. Sehingga dengan adanya pendidikan tersebut, maka akan tertanam bahwa pendidikan karakter sangatlah penting. Harapannya dengan adanya pendidikan karakter kepada anak-anak usia dini bisa membawa dampak yang signifikan kepada orang tua atau masyarakat, khususnya dalam membenahi karakter masyarakat untuk sadar bahwa bahaya sampah akan berdampak kepada lingkungan maupun kesehatan. Maka dari itu diperlukan sosialisasi yang intensif kepada anak-anak usia dini maupun orang tua.

Pada tahapan sosialisasi yang kami lakukan kepada siswa-siswi Sekolah Dasar Negeri

Singoyudan Kecamatan Mirit Kabupaten Kebumen diikuti dengan sangat antusias serta disambut 
baik oleh Kepala Sekolah maupun guru. Mengingat kegiatan ini sangatlah penting bagi anak-anak usia dini terutama dalam hal pengetahuan pengelolaan sampah. Beberapa guru tersebut juga mengatakan bahwa kegiatan ini seharusnya dilakukan sejak usia dini dan jika diperlukan seharusnya dimasukkan kedalam mata pelajaran, sehingga anak-anak bisa lebih memahami mengenai pemilahan sampai dengan pengelolaan sampah. Jika edukasi mengenai sampah sudah dilakukan sejak usia dini maka akan sangat bagus sekali untuk kebersihan lingkungan dan kesehatan diri sendiri maupun orang lain. Mengingat sampah merupakan salah satu sumber masalah baik bencana maupun kesehatan, akan tetapi sampah juga salah satu sumber perekonomian jika dikelola dengan baik. Maka dari itu anak-anak usia dini harus diajarkan untuk menghargai dan mengelola sampah dengan baik.

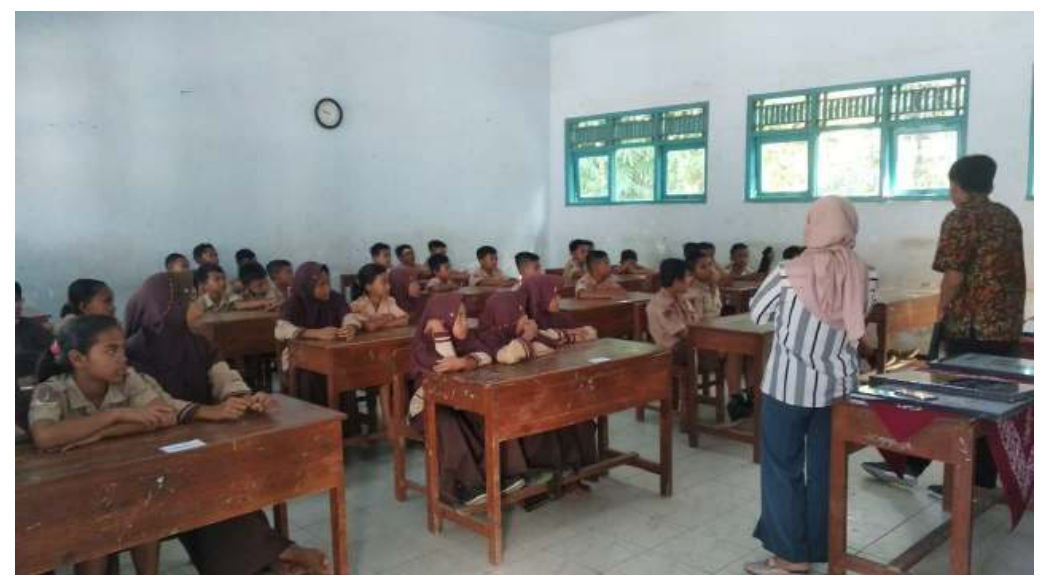

Gambar 2. Kegiatan Sosialisasi dengan Siswa-Siswi Kelas V dan IV

Sumber: Dokumentasi Tim Pengabdian 2019

Dengan diadakannya sosialisasi kepada siswa-siswi SD Negeri Singoyudan ini harapannya dapat meningkatkan pengetahuan anak-anak dalam mengelola sampah, baik mengelola sampah di sekolah maupun di rumah. Dengan menumbuhkan pendidikan pengelolaan sampah sejak dini harapannya adalah akan muncul generasi-generasi yang peduli terhadap lingkungan serta akan tumbuh pendidikan karakter bagi masyarakat tersebut. Mengingat paradigma pengelolaan sampah yang diterapkan masyarakat kita saat ini adalah paradigma lama dengan cara kumpulangkut dan buang. Paradigma tersebut sudah tidak efektif lagi untuk pengelolaan sampah sehingga perlu ada paradigma baru yang harus ditanamkan sejak usia dini kepada masyarakat kita. Adapun paradigma yang bisa dipakai mengenai pengelolaan sampah adalah Reduce, Reuse dan Recycle (3R).

Jika mengacu mengenai pengelolaan sampah berdasarkan Undang-Undang No 18 tahun 2008 tentang pengelolaan sampah, maka sampah harus dikelola dengan maksimal. Berdasarkan pernyataan (Subekti: 2010) bahwa upaya pengelolaan sampah dapat dilakukan dengan cara Reuse, Reduce, dan Recycle atau yang sering dikenal dengan istilah 3R. 3R merupakan kegiatan memperlakukan sampah dengan cara, menggunakan kembali, mengurangi dan mendaur ulang.

1. Reuse (menggunakan kembali): yaitu penggunaan kembali sampah secara langsung, baik untuk fungsi yang sama maupun fungsi lain.

2. Reduce (mengurangi): yaitu mengurangi segala sesuatu yang menyebabkan timbulnya sampah. 
3. Recycle (mendaur ulang): yaitu memanfaatkan kembali sampah setelah mengalami proses pengolahan.

Berikut ini contoh pengelolaan sampah di perkantoran, sekolah dan fasilitas umum dengan menggunakan metode Reuse, Reduce, dan Recycle (Subekti: 2010).

Tabel 1. Contoh Pengelolaan Sampah di Perkantoran, Sekolah dan Fasilitas Umum

\begin{tabular}{|c|c|}
\hline Reuse & $\begin{array}{l}\text { - Gunakan alat kantor yang dapat digunakan berulang-ulang. } \\
\text { - Gunakan peralatan penyimpan elektronik yang dapat dihapus dan } \\
\text { ditulis kembali. Gunakan sisi kertas yang masih kosong untuk menulis }\end{array}$ \\
\hline Reduce & $\begin{array}{l}\text { - Gunakan kedua sisi kertas untuk penulisan dan fotokopi. } \\
\text { - Gunakan alat tulis yang dapat diisi kembali. } \\
\text { - Sediakan jaringan informasi dengan komputer (tanpa kertas) } \\
\text { - Maksimumkan penggunaan alat-alat penyimpan elektronik yang } \\
\text { - dapat dihapus dan ditulis kembali. } \\
\text { - Kusus untuk rumah sakit, gunakan insinerator untuk sampah medis. } \\
\text { - Kurangi penggunaan bahan sekali pakai }\end{array}$ \\
\hline Recycle & $\begin{array}{l}\text { - Olah sampah kertas menjadi kertas kembali. } \\
\text { - Olah sampah organik menjadi kompos. }\end{array}$ \\
\hline
\end{tabular}

Sumber: Prosiding Seminar Nasional Sains dan Teknologi 2010 (Subekti:2010)

\section{KESIMPULAN}

Berdasarkan pelaksanaan pengabdian yang kami lakukan ada beberapa hal yang perlu diperhatikan, diantaranya adalah mengenai pemahaman tentang pengelolaan sampah yang belum dipahami oleh siswa secara merata maupun guru. Sehingga perlu adanya pelaksanaan sosialisasi untuk pemahaman kepada siswa dan guru tentang pengelolaan sampah dengan metode 3R. Pada tahap forum group discussion sebagian guru sudah ada yang memahami mengenai sampah organic dan anorganik, akan tetapi masih ada guru yang belum memahami hal tersebut. Sedangkan untuk kegiatan sosialisasi yang kami lakukan masih banyak siswa yang belum memahami mengenai pemilahan sampah organic dan sampah anorganic. Maka dari itu diperlukan alat peraga yang membantu siswa untuk memahami pemilahan sampah, sehingga dengan adanya alat peraga tersebut siswa bisa lebih paham mengenai sampah organic dan anorganik.

Dengan adanya beberapa kegiatan yang kami lakukan di SD Negeri Singoyudan Kecamatan Mirit Kabupaten Kebumen bisa membantu guru dan siswa dalam memahami pemilahan sampah maupun pengelolaan sampah melalui 3R. Dengan adanya pemahaman tersebut maka akan tertanam kepada siswa mengenai cinta lingkungan dan kebersihan sehingga pendidikan karakter dalam membuang sampah kepada siswa bisa berhasil. Adanya beberapa kasus mengenai masih adanya pemahaman siswa maupun guru yang belum mengerti tentang pengelolaan sampah maka diharapkan untuk kedepan pendidikan karakter tentang sampah bisa dilakukan sejak usia dini, alangkah lebih bagus jika pendidikan dini mengenai sampah bisa dijadikan salah satu mata pelajaran di Taman Kanak-Kanak dan Sekolah Dasar. Sehingga pendidikan karakter tentang sampah sudah bisa dipahami dan dilakukan sejak usia dini. 


\section{DAFTAR PUSTAKA}

Hoornweg, D., \& Bhada-Tata, P. (2012). WHAT A WASTE A: Global Review of Solid Waste Management. Washington: World Bank.

Hoornweg, D., Bhada-Tata, P., \& Kennedy, C. (2013). Waste Production Must Peak This Century. Nature, 502, 615-617. Retrieved from http://www.nature.com/news/environmentwaste-production-must-peak-this-century-1.14032

Jambeck, J. R., Geyer, R., Wilcox, C., Siegler, T. R., Perryman, M., Andrady, A., . . Law, K. L. (2015). Plastic waste inputs from land into the ocean. Science, 347(6223), 768-771. doi:10.1126/science.1260352

National Geographic Indonesia. (2016, Januari 30). Indonesia Darurat Sampah. Retrieved from National Geographic Indonesia: http://nationalgeographic.co.id/berita/2016/02/indonesia-darurat-sampah/1

Subekti, Sri. (2010). Pengelolaan Sampah Rumah Tangga 3r Berbasis Masyarakat. Prosiding Seminar Nasional Sains dan Teknologi 2010. Fakultas Teknik Universitas Wahid Hasyim Semarang. 